\title{
ADOLPHO LUTZ - AUTOR E PIONEIRO DO METTODO DE SEDI- MENTAÇÃO PARA O DIAGNÓSTICO DE OVOS DO S. MANSONI NAS FEZES
}

o mais singuiar direito intelectual do homem, ao lado da liberdade de pensamento, é o direito ao reconhecimento público da prioridade de "autoria", propriedade inalienável, que constitui um dos mais importantes postulados da ética universal. No campo cientifico o reconhecimento desse direito faz parte integrante da própria ciência; algumas vezes, porém, sobretudo nos casos de descoberta concomitante ou por falta de conhecimento de trabalho já publicado, tem-se atribuido prioridade a um determinado autor ou autores de técnicas $e$ metodos já descritos por outros, dando margem a omissão, discussões e querelas, quando não a flagrantes injustiças, até mesmo dando-se o nome de um autor ou autores a uma técnica "redescoberta" por eles, muitos anos depois da descoberta original. E o caso por exemplo do chamado método de sedimentação de Hoffman, Pons e Janer para o diagnóstico de ovos de. S. mansoni nas fezes, "redescoberto" em 1934 por esses autores, quando na realidade havia sido descrito de forma magistral por Adolpho Lutz, em 1919, portanto 15 anos antes.

Em trabalho magistral publicado por Adolpho Lutz nas Memórias do Instituto Oswaldo Cruz, em 1919 (vol. 11, págs. 121 a 150) intitulado "O Schistosomum e a Schistosomatose Segundo Observaçōes feitas no Brazil", este autor faz uma extensa revisão dos conceitos sobre o Schistosoma $e$ a esquistossomose, desde a descoberta do $\mathrm{S}$. haematobium no Egito, por Bilharz em 1851, até a época do seu trabalho onde descreve, minuciosamente, toda a morfologia e fisiologia do genero "Schistosomum" de forma completa, em partcular do S. mansoni, inclusive os mecanismos de infecção $e$ as técnicas de diagnóstico, trabalho pioneiro que representa praticamente tudo o que se conhece sobre o parasito até hoje.

No capitulo "Ovos de Schistosomum mansoni - caracteristicas dos ovos encontrados nas fezes", às páginas 128 desse trabalho, Lutz descreveu de forma cristalina o método de sedimentação com as seguintes palavras: "O exame torna-se mais fácil pela lavagem repetida das fezes, seguida de sedimentação simples ou centrifugaçāo. Com estas combina-se o uso do tecido de arame e de gaze de moleiro para reter todos os corpos mais grossos. Assim obtem-se um sedimento que contem quase exclusivamente corpúsculos amiláceos e ovos de parasito.j, sendo fácil examinar."

Ł um dever de justiça, pois, denominar-se o método de sedimentação como "METODO DE LUTZ" - em homenagem ao mais puro dos cientistas brasileiros, - grande Adolpho Lutz. 
ADOLPHO LUTZ (1855 - 1940), médico e clentista brasileiro, nascido no Rio de Janeiro, formou-se pela Universidade de Berna, Suiça, em 1880. Começou a sua vida profissional em Limeira, no interior de Săo Paulo. Em 1890 fol para o Havaí como espectalista em lepra, chegando a diretor do hospital Kalihi na liha de Molocal. Em 1893 voltou 20 Brasil, onde d1rigiu, em São Paulo, o Instituto Bacteriológtco que hoje tem o seu nome e que fol o primelro do gênero em toda a América do Sul; permaneceu como diretor desse Instituto até 1908 quando fci chamado por Oswaldo Cruz para chefiar um dos setores do Instituto de Manguinhos, onde trabalhou durante 32 anos. Publicou numerosos trabalhos sobre lepra, rinoscleroma, anemia tropical, ancilostomose, febre tifoide, peste, difteria, novas espécies de mosquitos do Brasil, leishmaniose, blastomicose, malária, esquistossomose e planorbídeus de água doce. Pela precisão, variedade, minúctas e serledade dos seus trabalhos 6 considerado como o mais completo dos pesquilsadores brasileiros no campo da patologia tropical. Faleceu no Rlo de Janeiro aos 85 anos de ldade depois de uma vida dedicada à pesquisa, fato bem demonstrado no livro editado pelo Conselho Nacional de Pesquisas em 1956, sobre a sua vida e a sua obra. 